\title{
Deposit Insurance Systems: Evolution, Risks, Development Trends
}

\author{
Nataliya A. Amosova ${ }^{1, *}$ Mikhail Yu. Sanakoev ${ }^{2, a}$
}

\author{
${ }^{1}$ Department of Banking and Financial Markets, Financial University under the Government of the Russian Federation, \\ Moscow, Russia \\ ${ }^{2}$ Department of Business Process Development, Sberbank Insurance, LLC, Moscow, Russia \\ ${ }^{\mathrm{a} E-m a i l: ~ M i k h a i l . S a n a k o e v @ ~ @ b e r i n s . r u ~}$ \\ *Corresponding author. E-mail: NAAmosova@fa.ru
}

\begin{abstract}
Economic recovery after crises and economic growth are the relevant objectives for many countries worldwide amid the pandemic. A special contribution to fulfilling these objectives can be a research on the essence, institutional framework, characteristics and efficiency of deposit insurance systems. This circle of issues presents the research subject of the present article. The purpose of the article is to identify the challenges to deposit insurance development and work out the possible solutions to respond to them, as well as to conduct expert assessment of the prospects of deposit insurance system development. The central point of the research within the present article is the comparative analysis of deposit insurance systems which optimize the way financial institutions, primarily credit organizations, attract funds from the population and business. The main results of the research include the development of the adopted approach $[1 ; 2]$ to understanding the essence of deposit insurance systems and the assessment of their sustainability and risks in relation to the challenge of ensuring economic growth; the identification of new research areas of insurance relations in the banking sector; comparative analysis and generalization of the development results of deposit insurance systems; and proposals for the development of deposit insurance systems.
\end{abstract}

Keywords: deposit insurance, deposit insurance system, deposit insurance risks, deposit insurance funding model

\section{INTRODUCTION}

As the crises of the last two decades have shown, the modern economic science cannon effectively perform its predictive function. Moreover, the existing theories, approaches, and methodological framework for economic research have to be revised. In the second decade of the 21 st century, a number of fundamentally new financial studies were carried out that revaluated the role of the financial sector, financial markets and the institutions of the economic system, both locally and globally. Currently, the impact of the financial sector on economic growth is being re-examined. The conviction about the essentially positive and strong influence of the financial sector on the general development of economic systems, which existed for a long time, is now open to question.

Some attempts are being made aimed at demonstrating the ambivalent influence of the financial

*Fund: The article is based on the results of the publicly funded research carried out by government order from the Financial University under the Government of the Russian Federation. sector development on the macroeconomic indicators of the economy of the country. Financial development is no longer identified with financial market depth exclusively but is a subject to a multiple factor analysis. The approach to assess financial development and financial systems using the " $4 \times 2$ framework", which specifically includes the measures of depth, access, efficiency, and stability of financial institutions and markets, has become widely applied. Based on this framework of financial system characteristics, the World Bank established a Global Financial Development Database (GFDD), which covers over a hundred indicators on the countries worldwide. In order to calculate the Financial Development Index (FDI) the International Monetary Fund applies the reduced " $3 \times 2$ matrix" that does not account for the indicator of stability of financial institutions and markets. Being integral, the FDI is derived from twenty indicators.

The research in the following areas is currently advancing: the contradictory nature of various financial development parameters; financial stability; sustainable development and inclusion; technological revolution 
and the measurement of access to finance; systemic risk management, the relation between regulation and financial stability, the assessment of the efficiency of the financial sector and its individual segments, the financial inclusion of the participants of economic life; the theories of sustainable finance and adaptive markets.

Both traditional and innovative research emphasize the profound importance of the development of insurance relations in terms of deposit insurance in particular [4], [16], which is considered a tool for ensuring the stability of financial institutions and markets.

\section{DEVELOPMENT OF DEPOSIT INSURANCE SYSTEMS}

\section{A. The principles and models of funding deposit insurance systems}

The primary purpose of the creation and operation of deposit insurance systems is to ensure the stability of the banking system of the country by means of reducing the risk of losing deposited funds, thus preventing panic among depositors. The additional goals may include protecting competition in the banking sector, enhancing the credibility of the banking system and gaining digital trust.

The International Association of Deposit Insurers (IADI) recognizes the first two of the above goals as the fundamental ones and identifies four categories of basic systemic institutions in deposit insurance systems ("Fig. 1 " and "Fig. 2") [19].

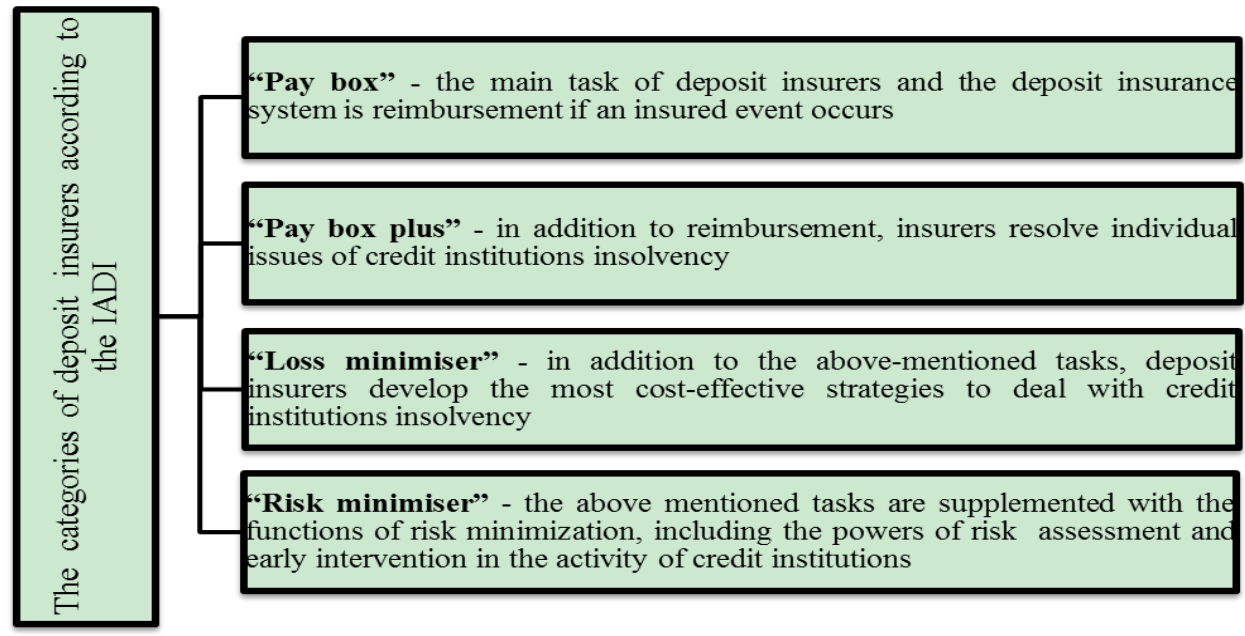

Fig. 1. The categories of deposit insurers according to the IADI.

Nowadays, the widely known 16 principles of deposit insurance system effectiveness can be supplemented by the new ones - the principles of cybersecurity of deposit insurance systems and technological efficacy.

The effectiveness of the deposit insurance system largely depends on the selected funding model. The a. Source: Compiled by the authors based on [16] IADI identifies two key models: ex-ante funding and ex-post funding ("Fig. 2"). Ex-ante funding mechanism is further divided into two subtypes: flat-rate premium model and differential premium model. The practicability of developing mixed (hybrid) models is also being assessed [6], [16], [20], [22]. 


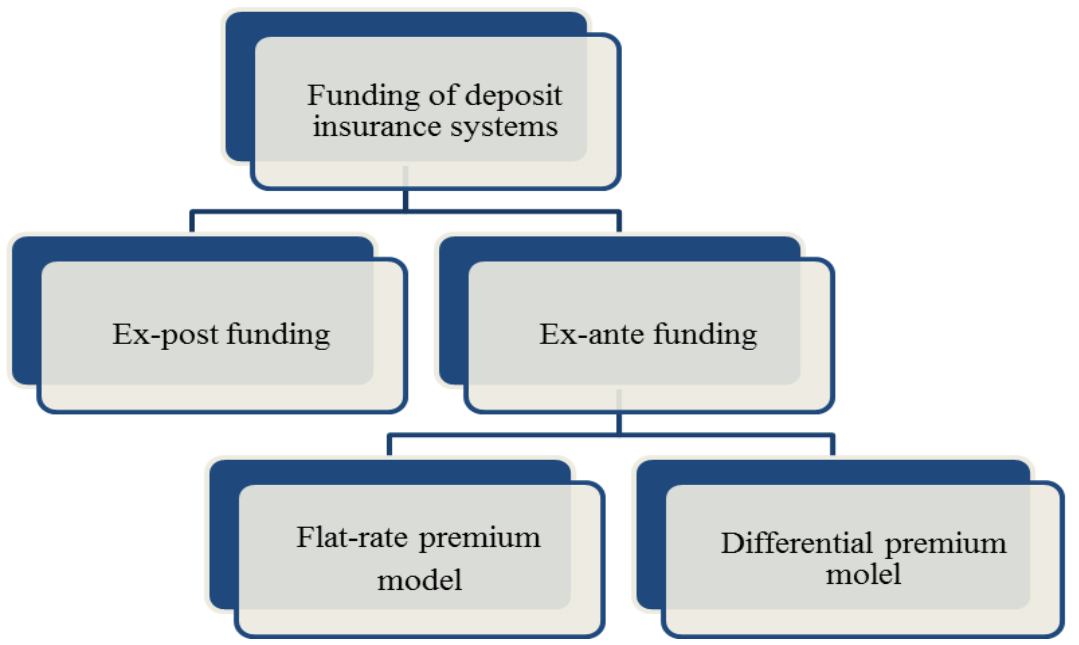

Fig. 2. Funding models of deposit insurance systems [16].

Ex-ante funding is considered more advanced and reliable than ex-post type, as financial resources are accumulated before an insured event occurs, i.e. before the actual failure of a bank. The corresponding fund is built up by regular payment of insurance premium by all participant credit institutions of the deposit insurance system.

The merits and demerits of different funding models of deposit insurance systems have been widely discussed; therefore, we shall not focus on them. It should only be highlighted that in the context of decreasing bank margins (which is the situation faced by the absolute majority of banks) and growing banking risks, regular payment of insurance premium poses a challenge for banks. This limits the available resources of credit institutions, but maintains public confidence in banks.

Within the ex-ante flat-rate premium model, all member institutions are assessed at the same rate, regardless of the risks. The ex-ante differential premium model implies differentiated rates, adjusted for the risk of their activities. Under the ex-post funding model, the resources are accumulated as needed, only after the insured event, when a failure of a member bank occurs. The experience of deposit insurance systems in the 20th and 21 st centuries has shown that each funding model of the deposit insurance system should have its regulatory tools.

\section{B. The evolution of deposit insurance systems: the characteristic features of the deposit insurance system of the Russian Federation}

As it is widely known, the first deposit insurance system to establish in the world was the USA one, which has been successfully functioning since 1934. It
Source: Compiled by the authors based on [16]. took almost half a century for it to develop, as different states introduced individual norms and practices of deposit protection. The crisis encouraged over $90 \%$ of the commercial banks operating at that time and over a third of reciprocal holdings communities to merge into a single system. The legal framework for the merge was the Banking Act of 1933 (Glass-Steagall), which provided for the establishment of the Federal Deposit Insurance Corporation (FDIC).

The FDIC was established with a contribution of 150 million dollars from the Treasury Department and 12 Federal Reserve Banks buying out ownership interest in the FDIC amounting to $50 \%$ of their accumulated profits for the beginning of 1933 . Moreover, each credit institution joining the system was liable to pay the affiliation fee of $0.5 \%$ of their deposit.

This law made the participation in the deposit insurance system mandatory for all banks of the Federal Reserve System, licensed by the Treasury Department. The rest of the credit institutions were to confirm their solvency to the regulatory authorities of their state and the FDIC and to join the system as well. The limit of reimbursement was 2,500 dollars per depositor, and the coverage immediately extended to both individual and legal persons. According to the official website of the FDIC, the maximum reimbursement was increasing quickly and significantly: up to 5,000 dollars in 1935, 10,000 dollars in 1950, 40,000 dollars in 1974, 100,000 dollars in 1980, and 250,000 dollars in 2008.

The key characteristics of the US deposit insurance system include the following: participation in a deposit insurance system is mandatory for all credit institutions operating in the USA, with no exception of foreign branch banks; the FDIC is government-owned; the mixed (hybrid) funding model is applied in the FDIC - 
in the conditions of economic stability, funding is secured by the contributions from member banks, while in case of a lack of funding government lending is allowed; the FDIC closely cooperates with government banking authorities; insurance covers both individual and legal persons with no exceptions stated (the coverage extends to interbank deposits and funds of government agencies and municipalities) [10], [11], [12], [13], [14], [15].

In Europe, the development of deposit insurance systems started with Finland, Norway and Czechoslovakia but was interrupted by the Second World War. The German system (1974) has a particular place in the evolution of deposit insurance systems, since the government did not take part in its establishment. In addition, unlike in the USA, initially, the participation in the German deposit insurance system was optional and became mandatory only several decades after. Each of the three types of institutions that accumulated deposits (private banks, savings banks and cooperative banks) had its own funds [15].

Since 1994, under the Directive 94/19/EU of the European Parliament dated May 30, 1994 "On deposit insurance systems", all EU member countries were to have at least one operating deposit insurance system. The reimbursement limit was 20,000 euros per depositor, but it was further increased up to 50,000 euros in 2009 and 100,000 euros in 2010. The bank participation in the deposit insurance system was mandatory. In 2014, following the Directive 2014/49/EU, the option of voluntary participation of banks in the deposit insurance system was limited. Additionally, if earlier the EU member countries were allowed to set higher reimbursement limits than those established by the Directive, now there is the equal limit of 100,000 euros in all countries. In fact, the European Union is developing the integrated deposit insurance system with a shared fund [9].

Having introduced a deposit insurance system to its population in 1962, India has become the leading Asian country in terms of deposit insurance system development. The main institution of the system is the Deposit Insurance and Credit Guarantee Corporation; the maximum reimbursement on deposits amounts to 100, 000 rupees (about 1,500 USA dollars).

In 1971, Japan established a mandatory deposit insurance system. The maximum reimbursement is 10 million yen (approximately 87,000 USA dollars), and the main system institution is the Deposit Insurance Corporation of Japan.

The deposit insurance systems of Hong Kong and the People's Republic of China were relatively late to establish. Hong Kong introduced a deposit insurance system in 2006, with the maximum reimbursement of
500,000 Hong Kong dollars (approximately 64,000 USA dollars). The deposit insurance system of the PRC appeared in 2015 and covered deposits of both individual and legal persons, with the reimbursement of 500, 000 yuan (approximately 76,000 USA dollars).

Islamic banking models are of a particular interest in the context of deposit insurance development [32]. The first deposit insurance system based on the ex-post funding model was introduced in 1993 in Bahrain.

Three years later, in 1996, the Islamic deposit insurance system with ex-ante funding appeared in Sudan.

The third Islamic deposit insurance system was privately initiated and developed in Turkey in 2001 , however, in a few years it was substituted by a national deposit insurance system.

In 2005, the Islamic deposit insurance system was developed in Malaysia. It should be stated that the Islamic financial world, as well as almost 150 other countries, is searching for adequate and appropriate forms and methods of the funding of deposit insurance systems.

In 2007, the Islamic Deposit Insurance Group was founded under the IADI auspices and aimed at working out the principles of the Sharia deposit insurance system for Islamic products.

The deposit insurance system of the Russian Federation was legitimated in 2003 on the adoption and approval of the law "On the deposit insurance of individuals in the banks of the Russian Federation" and started functioning in 2004. The Russian system of deposit insurance is based on the ex-ante flat-rate premium funding model. Originally, it covered individual persons only, but now individual entrepreneurs also have insurance coverage. Initially, the Deposit Insurance System Fund was formed by the asset contribution of the Russian Federation. In 2015, there was a shift towards the ex-ante differential premium funding model. According to the Deposit Insurance Agency, at the time of the deposit insurance system launch, reimbursement was limited to 100,000 roubles, which was subsequently revised at various times: up to 190,000 roubles in $2006,400,000$ roubles in $2007,700,000$ roubles in 2008 , and $1,400,000$ roubles in 2014.

\section{Regulatory and methodological framework for the operation of deposit insurance systems}

The regulatory framework for the operation of deposit insurance systems is established by national and international legislation and other regulatory documents.

The international regulatory framework is mainly constituted by the following IADI documents [17], [18], 
[19]: Guidance on the Resolution of Bank Failures (2006); Interrelationships Among Safety-Net Participants, (2006); Funding of Deposit Insurance Systems (2009); Public Awareness of Deposit Insurance Systems (2009); Governance of Deposit Insurance Systems (2009); The Establishment of a Legal Protection Scheme for Deposit Insurance System (2010); General Guidance for Developing Differential Premium Systems (2011); General Guidance for Developing Effective Reimbursement Systems and Processes (2012); Enhanced Guidance for Effective Deposit Insurance Systems: Public Awareness of Deposit Insurance Systems (2012); Enhanced Guidance for Effective Deposit Insurance Systems: Reimbursement Systems and Processes (2012); General Guidance on Early Detection and Timely Intervention for Deposit Insurance Systems (2013); Enhanced Guidance for Effective Deposit Insurance Systems: Deposit Insurance Coverage (2013); Enhanced Guidance for Effective Deposit Insurance Systems: Mitigating Moral Hazard (2013); IADI Core Principles for Effective Deposit Insurance Systems (2014); Dealing with Parties at Fault in a Bank Failure and Fraud in Deposit Insurance (2015); Enhanced Guidance for Effective Deposit Insurance Systems: Multiple Deposit Insurance Organizations (2015); Enhanced Guidance for Effective Deposit Insurance Systems: Ex Ante Funding (2015); Deposit Insurers' Role in Contingency Planning and System-wide Crisis Preparedness and Management (2019); Public Policy Objectives for Deposit Insurance Systems (2020).

The range of issues in these documents is relevant to the challenges that governments, regulators, insurers, depositors, and owners of financial institutions face.

The main regulatory for the deposit insurance system in the Russian Federation are the Federal Law No. 177-FZ "On deposit insurance in banks of the Russian Federation" dated December 23, 2003, the Federal Law No. 395-1 "On banks and banking activity" dated December 2, 1990, and the Federal Law No. 127-FZ "On insolvency (bankruptcy)" dated October 26, 2002.

Participation in the Russian deposit insurance system is mandatory for all operating credit institutions that accumulate deposits. The "Deposit Insurance Agency" (DIA) State Corporation, the owner of the Mandatory Deposit Insurance Fund, is responsible for the functioning and regulation of the system. The Deposit Insurance Agency falls into the "loss minimizer" category, as in addition to reimbursement to depositors, it also has the power of taking bankruptcy prevention measures and performing the functions of a bankruptcy commissioner in case of the failure of a credit institution. Meanwhile, the functions of risks identification and minimization in the banking sector remain the responsibility of the Bank of Russia. Russia employs the hybrid funding model of the deposit insurance system. The Deposit Insurance Agency collects regular (quarterly) premium from participating banks. In case of a limited funding, loans from the Bank of Russia can be provided, as well as subsidies from the public finance.

D. The hazards and risks of deposit insurance systems: ensuring the capital adequacy of banks that introduce new technologies as an indirect preventive way of risk management in deposit insurance systems

It is customary to assume that the major risk in deposit insurance systems is moral hazard. The management of this risk is assessed differently. Thus, in the United States, the primary focus is on minimizing moral hazard within the banking sector. The US deposit insurance system encourages banks to pursue the lowrisk financial policy, and the Federal Deposit Insurance Corporation does not regulate the unaccountable behaviour of depositors. In Russia, however, the deposit insurance system is primarily designed to reduce unaccountable depositor behaviour, and credit institutions are advised to control their own deposit policy risks only, not the risk of overall operations.

In deposit insurance systems based on ex-ante funding model, the main risks that require monitoring and management are the risk of unbalanced liquidity and the risk of system fund loss. Investment of the temporarily surplus funds in certain financial instruments is made in order to increase the funds or return them into economic circulation. Both the USA and the Russian Federation prioritize high-liquidity and low-risk financial instruments (US government bonds and deposits of the Bank of Russia, respectively), which do not fully return from the banking sector into the economy.

The risks of deposit insurance systems are primarily included into credit and market risks of commercial banks ("Fig. 3", "Table I") and pose a considerable threat. In this regard, it is interesting to highlight the proportion of non-performing and uncollectible loans in the total volume of loans in the Russian Federation and the monetary reserve for potential losses on loans, expressed as percentage of the total loans granted. Apparently, due to the pandemic and credit echoes of political risks, the emerging positive trend is likely to be adjusted downwards by January 1, 2021. 
12

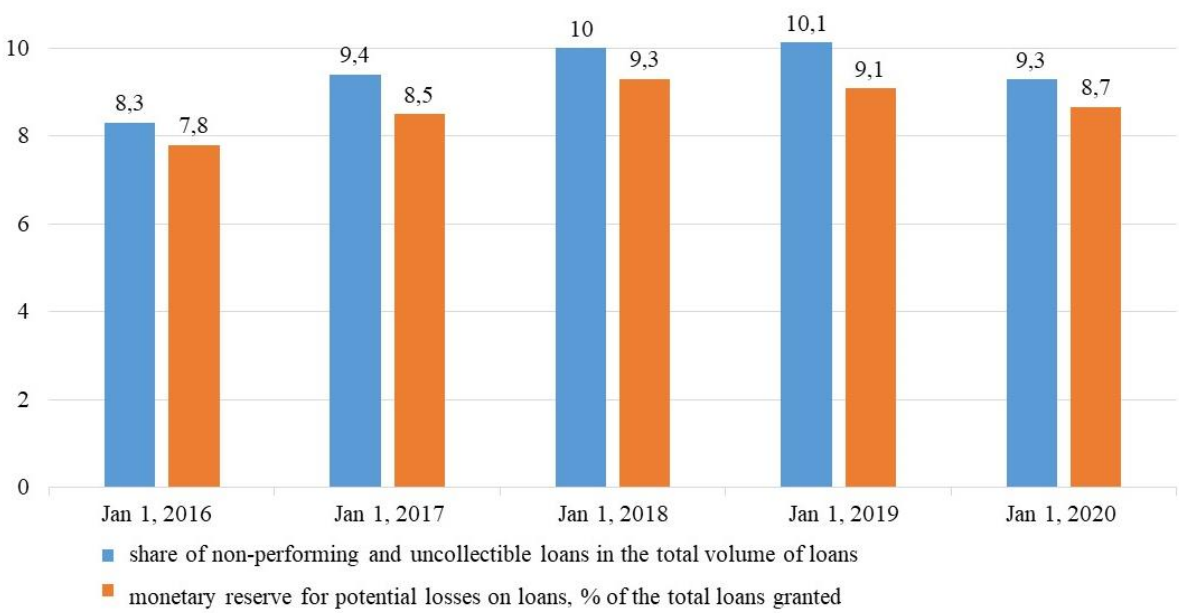

Fig. 3. Dynamics of the key indicators of credit risk of Russian commercial banks (2015-2019).

The sectoral statistics on credit risk as a hazard for the deposit insurance system is presented in "Table I":

TABLE I. DYNAMICS OF INDEBTEDNESS UNDER CREDITS PROVIDED BY RUSSIAN CREDIT INSTITUTIONS, \%

\begin{tabular}{|c|c|c|c|c|c|c|}
\hline Sectors & $\underset{1,2016}{J a n}$ & $\begin{array}{l}\text { Jan 1, } \\
2017\end{array}$ & $\begin{array}{l}\operatorname{Jan} 1, \\
2018\end{array}$ & $\underset{1,2019}{J a n}$ & $\begin{array}{c}\text { Jan 1, } \\
2020\end{array}$ & $\begin{array}{l}\text { Indicator } \\
\text { change over the } \\
\text { period, \% }\end{array}$ \\
\hline Agriculture, hunting, forestry & 3.5 & 4 & 4.1 & 4.1 & 3.8 & 0.3 \\
\hline Mining & 4.9 & 5.6 & 6.2 & 6.4 & 3.3 & -1.6 \\
\hline Manufacturing & 17.1 & 15.4 & 15.3 & 14.2 & 16.0 & -1.1 \\
\hline $\begin{array}{l}\text { Production and distribution of } \\
\text { electricity, gas and water }\end{array}$ & 2.5 & 3.1 & 3.2 & 2.9 & 2.6 & 0.1 \\
\hline Construction & 4.8 & 4.5 & 3.9 & 3.4 & 2.7 & -2.1 \\
\hline $\begin{array}{l}\text { Wholesale and retail trade, } \\
\text { repairing vehicles, household } \\
\text { items, and personal items }\end{array}$ & 11.3 & 10.9 & 9.5 & 9.5 & 8.3 & -3.0 \\
\hline Transport and communications & 4.2 & 4.2 & 4.2 & 5.0 & 4.5 & 0.3 \\
\hline Other activity types & 24.1 & 23.1 & 22.6 & 21.4 & 22.8 & -1.3 \\
\hline Individual persons & 27.5 & 29.1 & 30.9 & 33.0 & 36.0 & 8.5 \\
\hline
\end{tabular}

The risk profile of the deposit insurance system of Russia is formed not only by credit risks, but also by market risks of Russian commercial banks. As "Fig. 4" and "Fig. 5" demonstrate, we should expect the downside scenario with market risks at the end of 2020. 


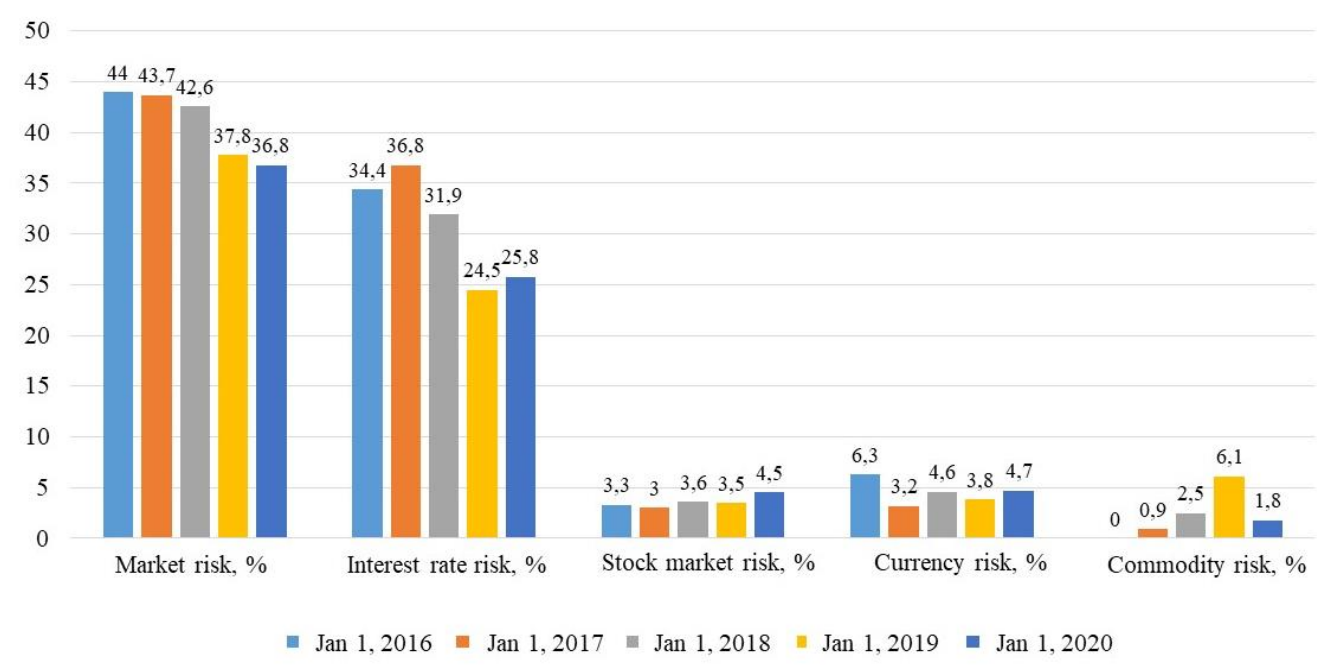

Fig. 4. Structure and dynamics of market risk and its components in Russian commercial banks (2015-2019).

a. Source: Compiled by the authors of the article based on the data from the Bank of Russia

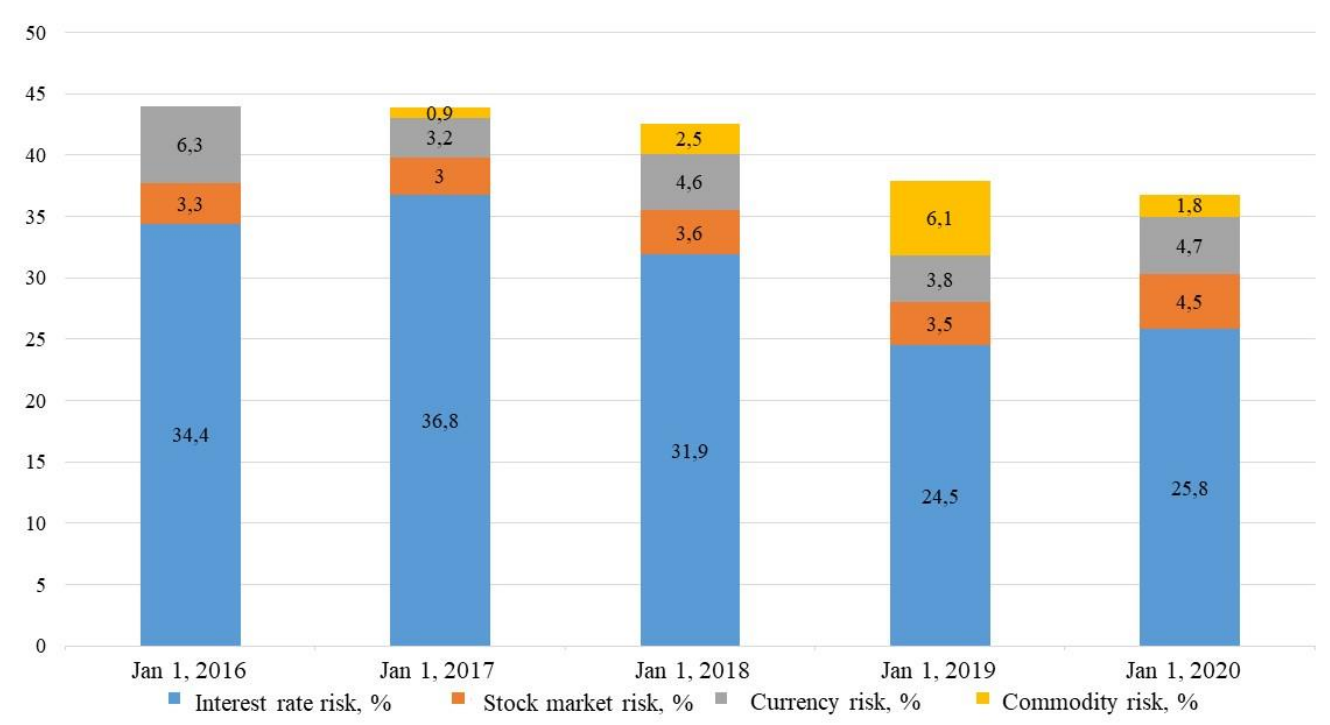

Fig. 5. Structure and dynamics of market risk and its components in Russian commercial banks (2015-2019).

Economic literature thoroughly discusses the impact of risks associated with the introduction of new financial technologies on the activity of commercial banks [3], [7], [23], [24], [27], however, their impact on identifying capital adequacy has not been studied yet.

Some relatively new risks for banks associated with the introduction of new technologies into their activities include: the downside risk of customer digital trust; the risk of bank income losses associated with the a. Source: Compiled by the authors of the article based on the data from the Bank of Russia restoration of the customers' violated digital rights; the risk of negative changes of the general risk profile of the bank; the risk of decreased capital adequacy of the bank due to money investment in technology introduction; and increased cyber risks. In our opinion, ensuring cybersecurity and capital adequacy of commercial banks that introduce new financial technologies $[25 ; 28 ; 31 ; 33]$ should be one of the forms of proactive risk management in deposit insurance systems. 
The introduction of new financial technologies alters the risk profile of commercial banks, which in its turn results in new risks appearing in addition to traditional risks that are primarily associated with decreasing digital trust of customers in commercial banks. However, the risk profile of the banks that do not implement new financial technologies is also changing, since they face the risks of competitive negligence: the banks that introduce new financial technologies serve customers faster and more efficiently and even anticipate customer needs, which cannot but make them more competitive than those not neglecting new financial technologies.

When initialling the use of new financial technologies, commercial banks have to develop approaches to assessing capital adequacy, monitor cyber risks, and introduce measures to reduce their impact on capital adequacy $[29 ; 30]$. Thus, ensuring the capital adequacy of commercial banks indirectly contributes to the optimization of the risk profile of deposit insurance systems. Our position on this issue is to some extent consistent with the current views of other researchers and institutions [5], [8], [21], [26], [27].

\section{E. The trends in the development of deposit insurance systems}

From our perspective, the following development trends are relevant for various deposit insurance systems:

- searching for the appropriate funding model and instruments;

- overcoming insurance poverty threshold of some financial institutions;

- increasing the reimbursement limit;

- expanding the range of deposits that fall under the deposit insurance system;

- ensuring cybersecurity of deposit insurance systems (of insurers, policy holders, insured persons);

- reasonable development of new financial and information technologies applied in the process of deposit insurance system operation.

\section{CONCLUSION}

As demonstrated by the review of the scientific literature on national deposit insurance systems, their functioning, the appropriate models for insurance protection of depositors, the behaviour of the participants of deposit insurance systems, the factors ensuring the sustainability of deposit insurance systems, despite considerable research, a wide range of issues have not been covered, including the issues of risk profile management and sustainability of national deposit insurance systems. The attempts to find applicable reference research in this area have not proved successful.

As the analysis of the legal and regulatory framework on the operation of deposit insurance systems shows, the International Association of Deposit Insurers effectively performs its functions; its documents enable national and regional legislation in the subject area under research. Meanwhile, from our perspective, the issue of proactive risk management of deposit insurance systems requires special attention.

The activity of the International Association of Deposit Insurers (IADI) in developing core principles for the operation of deposit insurance systems should be considered effective. However, the recent technological, political, competitive and epidemiological changes in the world have resulted in a significant transformation of banking and modified the requirements for government support and regulation of the financial sector. Moreover, the well-known 16 basic principles of effective deposit insurance systems should be updated and supplemented, for example, with the principles of cybersecurity of deposit insurance systems and technological efficacy.

The deposit insurance systems of different countries faced crisis at different stages of their development; accordingly, specified measures to improve their operation are required. Nevertheless, there are some general development trends relevant for different countries, such as optimization of system funding; increasing the reimbursement limit; expanding the range of deposits covered by insurance systems; overcoming insurance poverty threshold of some financial institutions; cybersecurity of deposit insurance systems (of insurers, policy holders, insured persons); developing the existing and introducing new financial and information technologies.

\section{References}

[1] Amosova, N.A. Banking risk insurance system: monograph Yu.A. Sokolov, N.A. Amosova. Moscow: Elite. 2003. 288 p.

[2] Amosova, N.A. Banking insurance in a transition economy: monograph. Moscow: Elite, 2003. 488 p.

[3] Ajay U.B. Nanjundaswamy S.K. Bank Data Certification and Repurposing Using Blockchain / Usha B. Ajay, Sangeetha K. Nanjundaswamy / BMS Institute of Technology and Management, India // Architectures and Frameworks for Developing and Applying Blockchain Technology, 2019, pp 222-245. Available at: https://www.igiglobal.com/chapter/bank-data-certification-and-repurposingusing-blockchain/230198

[4] Apergis N. Poufinas T. The role of insurance growth in economic growth: Fresh evidence from a panel of OECD countries / Nicholas Apergis, Thomas Poufinas // The North American Journal of Economics and Finance, 2020. Vol. 53. 
Available

https://www.sciencedirect.com/science/article/abs/pii/S1062940 820301145

[5] Ashraf B. Zheng C. Jiang C. Capital regulation, deposit insurance and bank risk: International evidence from normal and crisis periods / Badar Nadeem Ashraf, Changjun Zheng, Chonghui Jiang // Research in International Business and Finance, 2020. Vol. 52. Available at: https://www.sciencedirect.com/science/article/abs/pii/S0275531 918311231

[6] Camara A. Davidson T. Fodor A. Bank asset structure and deposit insurance pricing / Antonio Camara, Travis Davidson, Andrew Fodor // Journal of Banking \& Finance, 2020. Vol. 114. Available https://www.sciencedirect.com/science/article/abs/pii/S0378426 620300662

[7] De Bandt O. Hartmann P. Systemic Risk in Banking after the Great Financial Crisis / Olivier De Bandt, Philipp Hartmann / The Oxford Handbook of Banking, 2019, pp. 848-891. Available

https://www.oxfordhandbooks.com/view/10.1093/oxfordhb/978 0198824633.001.0001/oxfordhb-9780198824633

[8] Deposit Insurance Agency. Financial Innovations: Risks and Opportunities / N. Evstratenko Available at: https://www.dicgc.org.in/pdf/Speeches/FinancialInnovationsRis ksandOpportunities.pdf (Access date: July 9, 2020)

[9] European Banking Authority. Deposit Guarantee Schemes data. Available at: https://eba.europa.eu/regulation-andpolicy/recovery-and-resolution/deposit-guarantee-schemes-data (Access date: July 5, 2020)

[10] Federal Deposit Insurance Corporation. Annual reports. Available https://www.fdic.gov/about/strategic/report/index.html (Access date: July 5, 2020)

[11] Federal Deposit Insurance Corporation. FDIC Assessment Rates. Available at: https://www.fdic.gov/deposit/insurance/assessments/proposed.ht $\mathrm{ml}$ (Access date: July 1, 2020)

[12] Federal Deposit Insurance Corporation. FDIC Law, Regulations, Related Acts. Available at: https://www.fdic.gov/regulations/laws/rules/ (Access date: July $1,2020)$

[13] FDIC Quarterly 2020 Volume 14, Number 1. Available at: https://www.fdic.gov/bank/analytical/quarterly/2020-vol141/fdic-v14n1-4q2019.pdf (Access date: July 5, 2020)

[14] Federal Deposit Insurance Corporation. Reserve Ratio. Available at: https://www.fdic.gov/deposit/insurance/reserveratio.html (Access date: July 3, 2020)

[15] Fecht F. Thum S. Weber P. Fear, deposit insurance schemes, and deposit reallocation in the German banking system / Falko Fecht, Stefan Thum, Patrick Weber // Journal of Banking \& Finance, 2019. Vol. 105 pp. 151-165. Available at: https://www.sciencedirect.com/science/article/abs/pii/S0378426 619301025

[16] Funding of Deposit Insurance Systems, 2009. Available at: https://www.iadi.org/en/assets/File/Papers/Approved\%20Guida nce\%20Papers/Funding\%20Final\%20Guidance\%20Paper\%206 _May_2009.pdf (Access date: July 25, 2020)

[17] International Association of Deposit Insurers. Approved Guidance Papers. Available at: https://www.iadi.org/en/coreprinciples-and-research/papers/ (Access date: July 1, 2020)

[18] International Association of Deposit Insurers. Deposit Insurance Systems Worldwide. Available at: https://www.iadi.org/en/deposit-insurance-systems/disworldwide/\#4 (Access date: July 25, 2020)
[19] IADI Core Principles for Effective Deposit Insurance Systems. Available https://www.iadi.org/en/assets/File/Core\%20Principles/cprevise d2014nov.pdf (Access date: July 25, 2020)

[20] Johari E.E. Chronopoulos D. Scholtens B. Deposit insurance and bank dividend policy / Edie Erman Che Johari, Dimitris K. Chronopoulos, Bert Scholtens // Journal of Financial Stability, 2020. Vol. 48. Available at: https://www.sciencedirect.com/science/article/abs/pii/S1572308 920300231

[21] Ji Y. Bian W. Huang Y. Deposit insurance, bank exit, and spillover effects / Yang Ji, Wenlong Bian, Yiping Huang // Journal of Banking \& Finance, 2018. Vol. 96 pp. 268-276. Available https://www.sciencedirect.com/science/article/abs/pii/S0378426 618302000

[22] Kusairi S. Sanusi N.A. Ismail A.G. Dilemma of deposit insurance policy in ASEAN countries: Does it promote banking industry stability or moral hazard? / Suhal Kusairi, Nur Azura Sanusi, Abdul Ghafar Ismail // Borsa Istanbul Review, 2018. Vol. 18 pp. 33-40. Available at: https://www.sciencedirect.com/science/article/pii/S2214845017 300558

[23] Lentzis D. Revisiting the Basics of EU Data Protection Law: On the Material and Territorial Scope of the GDPR/ Dimosthenis Lentzis / Aristotle University of Thessaloniki, Greece // Personal Data Protection and Legal Developments in the European Union, 2020, pp. 19-33. Available at: https://www.igi-global.com/chapter/revisiting-the-basics-of-eudata-protection-law/255190

[24] Le T.N. Nasir M.A. Capital requirements and banks performance under Basel-III: A comparative analysis of Australian and British banks / Thi Ngoc Lan Le, Muhammad Ali Nasir // The Quarterly Review of Economics and Finance, 2020. Vol. 74. Available at: https://www.sciencedirect.com/science/article/abs/pii/S1062976 920300740

[25] Neves A. Protection of Personal Data Regulation and Public Liberties: A Polyhedron With Unexpected Effects / Ana Neves / School of Law, University of Lisbon, Portugal // Personal Data Protection and Legal Developments in the European Union, 2020, pp. 1-18. Available at: https://www.igiglobal.com/chapter/protection-of-personal-data-regulation-andpublic-liberties/255189

[26] Ojo M. Capital Requirements Directive (CRD) IV: Globa Developments / Marianne Ojo / George Mason University, USA // Uncertainties and Risk Assessment in Trade Relations, 2018 , pp. 242-259. Available at: https://www.igiglobal.com/chapter/capital-requirements-directive-crdiv/196294

[27] Ojo M. Proposals to Strengthen Global Capital and Liquidity Regulations/ Marianne Ojo / George Mason University, USA // Uncertainties and Risk Assessment in Trade Relations, 2018 , pp. 260-278. Available at: https://www.igiglobal.com/chapter/proposals-to-strengthen-global-capital-andliquidity-regulations/196295

[28] Singh D. Nath I. Singh P.K. Security and Privacy: Challenges in Big Data / Dharmpal Singh, Ira Nath, Pawan Kumar Singh / JISCE, India // Security, Privacy, and Forensics Issues in Big Data, 2019, pp. 97-124. Available at: https://www.igiglobal.com/chapter/security-and-privacy-challenges-in-bigdata/234807

[29] Sanakoev, M.Yu. Capital adequacy of commercial banks and the introduction of new financial technologies: identification of interdependence. Banking services - 2019. No. 10. Pp. 27-33. 
[30] Sanakoev, M.Yu. Risks of commercial banks introducing new financial technologies and ensuring capital adequacy. Banking services - 2019. No. 12. Pp. 12-18.

[31] Yıldırım I. Cyber Risk Management in Banks: Cyber Risk Insurance / Ismail Yıldırım / Hittite University, Turkey // Global Cyber Security Labour Shortage and International Business Risk, 2018, pp. 38-50. Available at: https://www.igiglobal.com/chapter/cyber-risk-management-in-banks/213445

[32] Zain N.R. Hassan R. Enhancing Islamic Banking and Finance in Southeast Asia Through the Application of Artificial Intelligence: An Exploration of Banking's Best Practices / Nor Razinah Mohd. Zain, Rusni Hassan / IIUM Institute of Islamic Banking and Finance, International Islamic University Malaysia // Impact of Financial Technology (FinTech) on Islamic Finance and Financial Stability, 2019, pp. 36-53. Available at: https://www.igi-global.com/chapter/enhancing-islamic-bankingand-finance-in-southeast-asia-through-the-application-ofartificial-intelligence/236797

[33] Zhang X. Human Factors in Cybersecurity: Issues and Challenges in Big Data / Xichen Zhang / University of New Brunswick, Canada // Security, Privacy, and Forensics Issues in Big Data, 2019, pp. 66-96. Available at: https://www.igiglobal.com/chapter/human-factors-in-cybersecurity/234806 